Excretion in Hepatic Cirrhosis, A.M.A. Arch. intern. Med., 108, 41.

FreNCH, H. (1909): Sixty Cases of Pernicious Anæmia, Guy's Hosp. Rep., 63, 2.

Granville, N., and DAMESHEK, W. (1958): Hæmochromatosis with Megaloblastic Anæmia. Response to Folic Acid Therapy, New Engl. J. Med., 258, 586.

HaRvier, P., and MallaRme, J. (1938): Biermer Disease of Hepatomegalic Form with Pigmentations Simulating Pigmentary Cirrhosis, Sang., 12, 883.

HerberT, V. (1962): Minimal Daily Adult Folate Requirement, A.M.A. Arch. intern. Med., 110, 649.

HoTZ, H. W. (1944): Lebercirrhose und Hämatopose, Ergebn. inn. Med. Kinderheilk, 64, 198.

ImmermanN, H. (1879): Ueber Progressive Perniziöse Anämie, Dtsch. Arch. klin. Med., 13, 209.
JANDL, J. H. (1955): The Anæmia of Liver Disease, Observations on its Mechanism, J. clin. Invest., $\frac{3}{12}$
34, 390.

JANDL, J. H., and LEAR, A. A. (1956): Metabolisme. of Folic Acid in Cirrhosis, Ann. intern. Med., 45, 1027.

KoszewSKI, B. J. (1952): The Occurrence of Megalo blastic Erythropoiesis in Patients with Hemochromatosis, Blood, 7, 1182.

MAIER, C. (1957): Hyperchromic Anæmia in $\frac{\bar{m}}{\frac{1}{2}}$ Hæmochromatosis caused by Vit. $\mathbf{B}_{6}$ Deficiency, Schweiz. med. Wschr., 87, 39.

Muller, H. (1877): "Die Progressive Perniziöseê

Anämie, Zürich: Schmidt.
RoTH, O. (1915): Zur Pathogenese und Klinik der $\vec{\circ}$ Hämochromatose, Dtsch. Arch. klin. Med., 117, $\overrightarrow{\vec{\omega}}$ 224.

\title{
NEPHROTIC SYNDROME DUE TO THROMBOSIS OF THE INFERIOR VENA CAVA AND RENAL VEINS
}

\author{
T. J. BAYLEY, M.B., M.R.C.P. \\ Donald Heath, M.D., Ph.D., M.R.C.P. \\ J. HaRdwiCKe, M.D., B.Sc. \\ A. G. W. WhitField, M.D., Ph.D., F.R.C.P \\ Departments of Medicine, Pathology and Experimental Pathology, Queen Elizabeth Hospital, \\ University of Birmingham.
}

FIFTY years ago, Rowntree, Fitz and Gerachty (1913) described the proteinuria which occurred in animals following obstruction of the inferior vena cava proximal to the renal veins or of the renal veins themselves. In the same year Shattock (1913) recorded the case of Dr. Rivers Pollock, the obstetric physician to the Westminster Hospital, who sustained a traumatic thrombosis of the inferior vena cava and thereafter had gross albuminuria which persisted until his death 25 years later from streptococcal septicæmia. It was not until 1939 that the first full description of the nephrotic syndrome associated with thrombosis of the renal veins and inferior vena cava appeared (Derow, Schlesinger and Savitz, 1939). Since then other cases have been recorded (Blainey, Hardwicke and Whitfield, 1954; Harrison, Milne and Steiner, 1956; Pollak, Kark, Pirani, Shafter and Meuhrcke, 1956; Hasson, Berkman, Parker and Rifkin, 1957; Blainey, Brewer, Hardwick and Scothill, 1960). This communication describes a further patient observed closely from onset to death from uræmia eight years later and in whom there were many features of particular interest.

\section{Case Report}

In April 1955 a previously fit male aged 27 years used a breast drill from the right groin for some hours and the following day he experienced a severe aching pain in this region. Twenty four hours later the whole of the right leg became swollen and he wass admitted to the Royal Salop Infirmary where he wasgiven ten days heparin therapy under which the pain and swelling subsided. Two weeks later œdema of the right leg recurred and he was given anticoagulant therapy with phenindione for seven weeks after which he returned to work and wore an elastic stocking은 In December 1955 the left leg became odematous and he was re-admitted to the Royal Salop Infirmary Massive albuminuria was found, phenindione therapy was recommenced and on 17th March, 1956 he was transferred to the Queen Elizabeth Hospital, Birming ham. At this time collateral venous channels wereevident on the trunk (Fig. 1) and both legs and the lumbo-sacral region of the back were grossly? œedematous. The blood pressure was $135 / 80 \mathrm{~mm}$. Hg尺 The urinary protein loss fluctuated between 9 and $15 \mathrm{~g}$. daily and the deposit showed $1143 \times 10^{\circ}$ red blood cells, $15 \times 10^{8}$ white blood cells, $0.2 \times 105$ hyaline casts and $0.1 \times 10^{6}$ granular casts in twenty four hours (Fig. 2). The blood urea was $35 \mathrm{mg}$. 1100 $\mathrm{ml}$. and the creatinine clearance $119 \mathrm{ml}$./min. The serum cholesterol was $370 \mathrm{mg} . / 100 \mathrm{ml}$. and the serum protein $5.3 \mathrm{~g} . / 100 \mathrm{ml}$. of which the albumiñ was $2.20 \mathrm{~g} . / 100 \mathrm{ml}$. The serum complement fluctuated between 0.8 and 1.0 units $/ \mathrm{ml}$. The chest radiograplu showed a normal cardiac silhouette and clear lung fields. An intravenous pyelogram revealed no abnormality apart from rather dense renal shadow

Renal biopsy showed no normal glomeruli. In ald there was some degree of hyalinisation patchily distributed within the glomeruli. Glomerularo adhesions and periglomerular fibrosis were presen? in some glomeruli. The tubules were mainly normag 

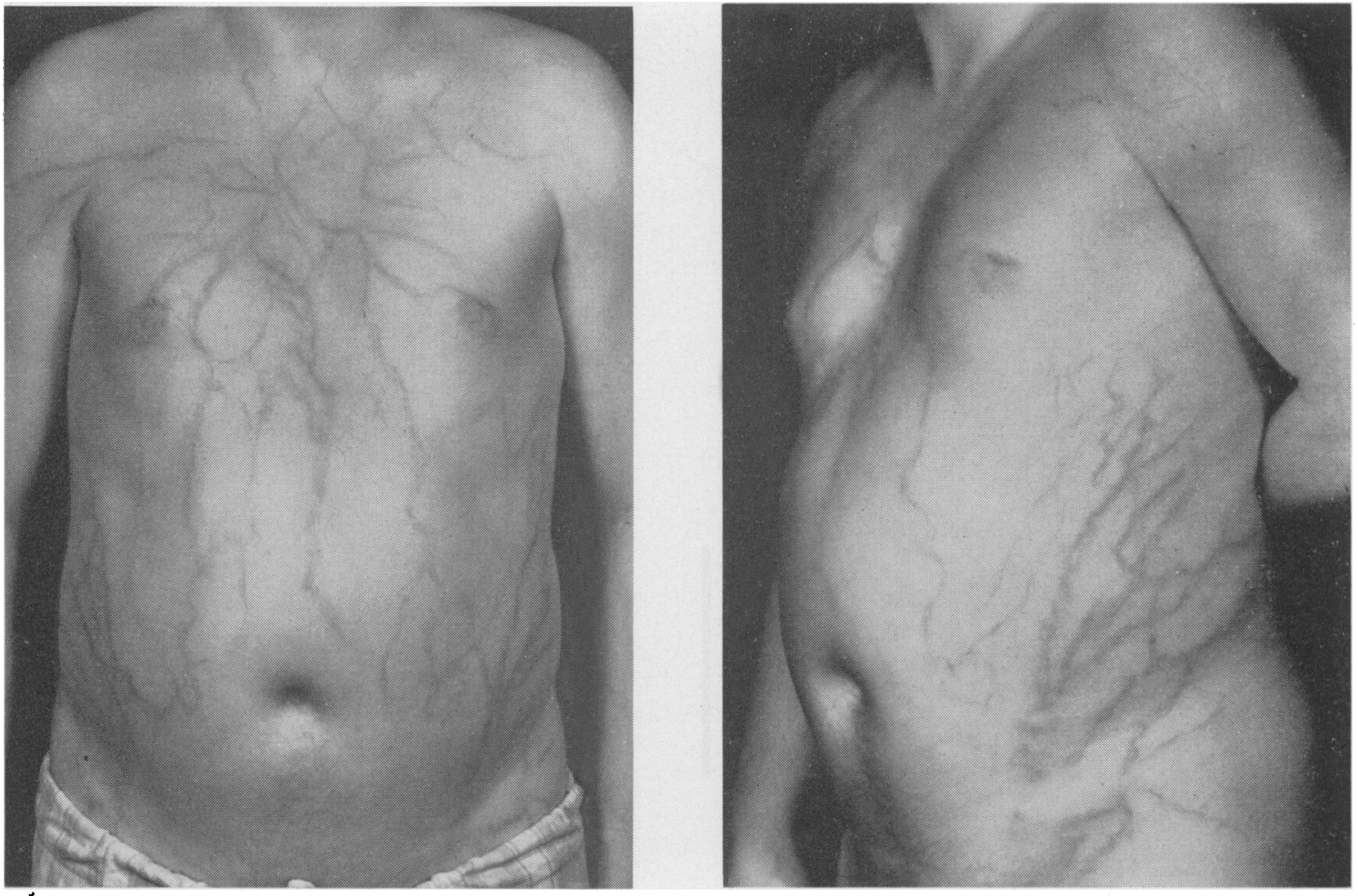

Fig. 1.-Venous collaterals on the trunk. March 1956.

but there was a slight diffuse increase in interstitial fibrous tissue (Fig. 3); these lesions were classified as "membranous glomerulonephritis", the glomerular lesion typically associated with renal vein thrombosis (Blainey, Brewer, Hardwicke and Soothill, 1960). Phenindione therapy was continued, cortisone was given in a dose of $100 \mathrm{mg}$. daily and the patient took a high protein, low salt diet.

Over the course of the next year there was no alteration in the venous collaterals and no diminution in the urinary protein loss and steroid and anticoagulant therapy were therefore discontinued.

High protein feeding had, however, produced a considerable rise in the serum albumin level (Fig. 2) and odema was then only minimal and localised to the legs; this was presumed to be due to the inferior vena caval obstruction. The red cell content of the urine diminished progressively to a level of $6 \times 10^{6}$ in twenty four hours in September 1957 by which time, however, a significant fall in creatinine clearance was evident (Fig. 2) and the blood pressure had begun to rise $(160 / 105)$. Immunochemical protein clearances (Table 1) showed poorly selective proteinuria. During the next five years the patient remained subjectively well and at work but the urinary protein loss continued unabated though the high protein intake produced a progressive rise in the serum albumin level to $3.59 \mathrm{~g} . / 100 \mathrm{ml}$. in September 1959. At this time the creatinine clearance had fallen to $33 \mathrm{ml}$. $/ \mathrm{min}$. and the blood urea had risen to $80 \mathrm{mg} . / 100 \mathrm{ml}$. A rise in the white cell content of the urine to $310 \times 10^{6}$ in twenty-four hours suggested the possibility of a superimposed pyelonephritic element and over the next eighteen months sulphamethoxypyridazine, tetracycline and sulphamethazine were successively prescribed. This therapy reduced the white cell content of the urine to $10 \times 10^{6}$ in twenty-four hours and appeared to prevent for a time any further rise in the blood urea or blood pressure or fall in the creatinine clearance. In February 1961 an intravenous pyelogram showed kidneys still of normal size and very faint excretory shadows. The urinary protein loss increased to 15-20 g. daily and by August 1962 the blood urea had risen to $140 \mathrm{mg} . / 100 \mathrm{ml}$., the creatinine clearance had fallen to $11 \mathrm{ml} . / \mathrm{min}$., the serum calcium was $8.9 \mathrm{mg}$./ $100 \mathrm{ml}$., the serum phosphorus $7.6 \mathrm{mg} . / 100 \mathrm{ml}$., the standard bicarbonate $13.8 \mathrm{~m}$. Eq./L and the hæmoglobin $57 \%$. During the remaining four months of the patient's life he was given $10 \mathrm{mg}$. prednisone daily, repeated blood transfusions and a low protein diet. Oral sodium bicarbonate maintained a normal blood $\mathrm{pH}$ and standard bicarbonate. Increasing hypertension (to $230 / 130 \mathrm{~mm}$. $\mathrm{Hg}$.) produced left ventricular hypertrophy, electrocardiographic left ventricular dominance and left ventricular failure and though the blood pressure was controlled with mecamylamine and he was kept fully digitalised. Increasing cdema developed, the blood urea rose (to $372 \mathrm{mg}$./100 ml.), phosphate retention increased and he died a uræmic death with terminal pericarditis on 28th January, 1963.

Necropsy. At autopsy the kidneys were found to be small and pale and weighed $210 \mathrm{~g}$. The cortex 


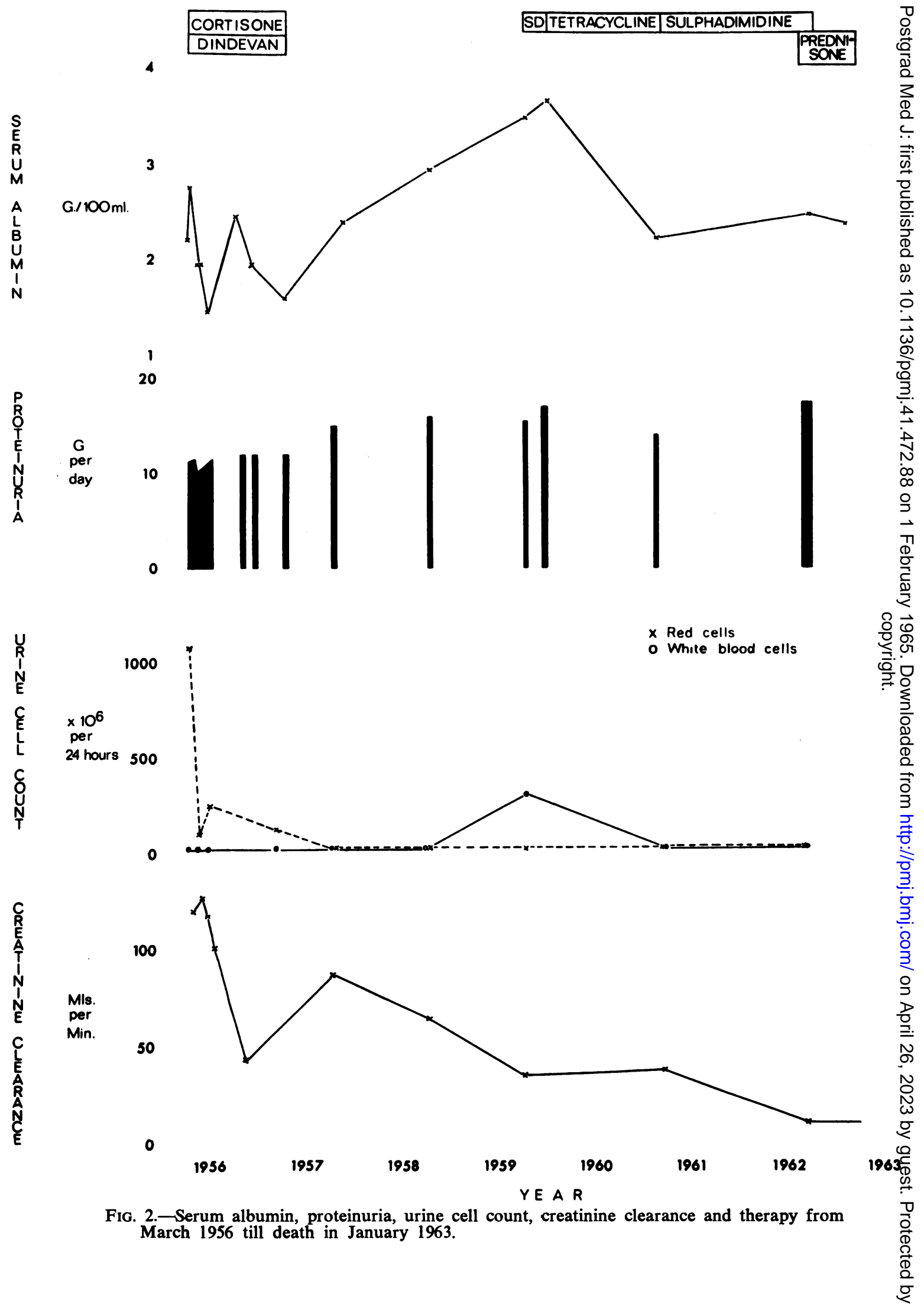




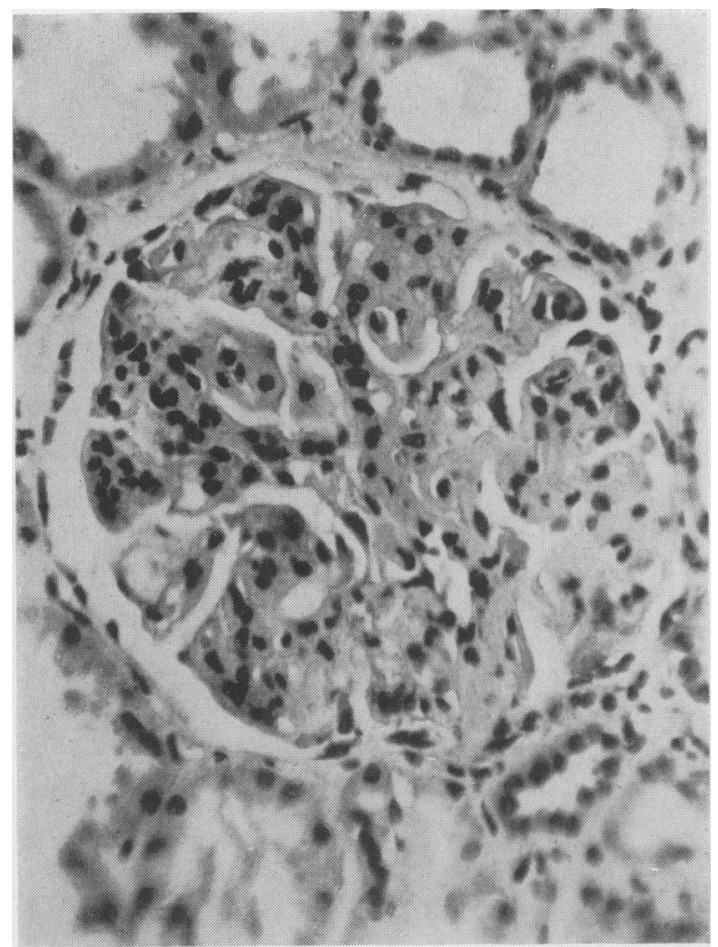

Fig. 3.-Renal biopsy. March 1956.

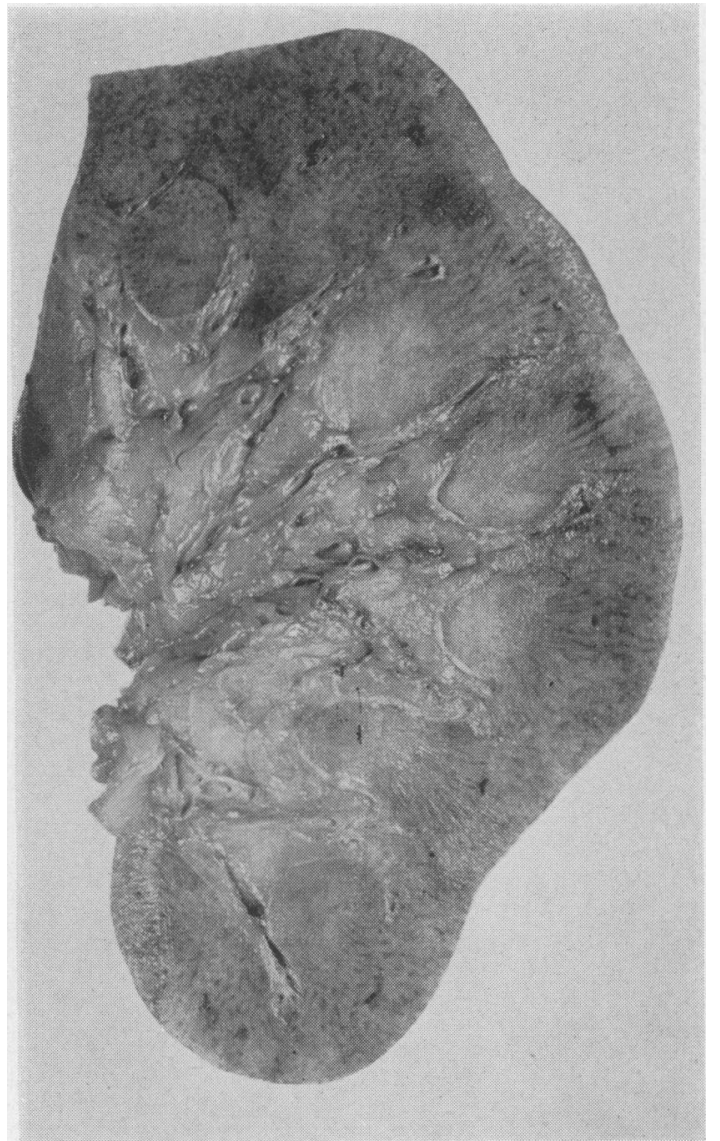

FIG. 4.-Postmortem appearance of kidney. Thin cortex and poor corticomedullary demarcation.

TABLE 1

IMMUNOCHEMICAL PROTEIN CLEARANCES

\begin{tabular}{|c|c|c|c|c|c|c|}
\hline \multirow[b]{2}{*}{$\begin{array}{l}\text { Albumin } \\
\text { Siderophilin } \\
\gamma \text {-Globulin } \\
\text { Coeruloplasmin } \\
\text { Complement }\left(\mathbf{C}^{\mathbf{d}}{ }_{\mathbf{z}}\right) \\
\boldsymbol{\alpha}_{2} \text {-Glycoprotein } \\
\boldsymbol{\beta} \text {-Lipoprotein }\end{array}$} & \multicolumn{2}{|c|}{$\begin{array}{l}\text { Urine / Plasma } \\
\text { Protein Ratio }\end{array}$} & \multicolumn{2}{|c|}{$\begin{array}{c}\text { Serum } \\
\text { Concentration } \\
(\% \text { of Normal) }\end{array}$} & $\frac{\text { Clearance }}{\text { Albumin Clearance }} \%$ & $\frac{\text { Clearance }}{\text { Siderophilin Clearance }} \%$ \\
\hline & $\begin{array}{l}2.10 .58 \\
1 / 8 \\
1 / 8 \\
1 / 16 \\
1 / 8 \\
1 / 16 \\
1 / 64 \\
0\end{array}$ & $\begin{array}{c}21.8 .62 \\
5 / 16 \\
1 / 4 \\
1 / 32 \\
-1 / 8 \\
1 / 128 \\
1 / 256\end{array}$ & $\begin{array}{c}2.10 .58 \\
50 \\
200 \\
100 \\
100 \\
\overline{-} \\
150\end{array}$ & $\begin{array}{c}21.8 .62 \\
87 \\
100 \\
50 \\
\frac{87}{87} \\
100 \\
100\end{array}$ & $\begin{array}{c}2.10 .58 \\
100 \\
100 \\
50 \\
100 \\
50 \\
12 \\
0\end{array}$ & $\begin{array}{c}21.8 .62 \\
125 \\
100 \\
87 \\
\frac{5}{50} \\
3 \\
1.5\end{array}$ \\
\hline
\end{tabular}

Albumin Clearance $(2.10 .58)=0.225 \mathrm{ml} . / \mathrm{min}$.

Siderophilin Clearance $(21.8 .62)=0.45 \mathrm{ml} . / \mathrm{min}$. 


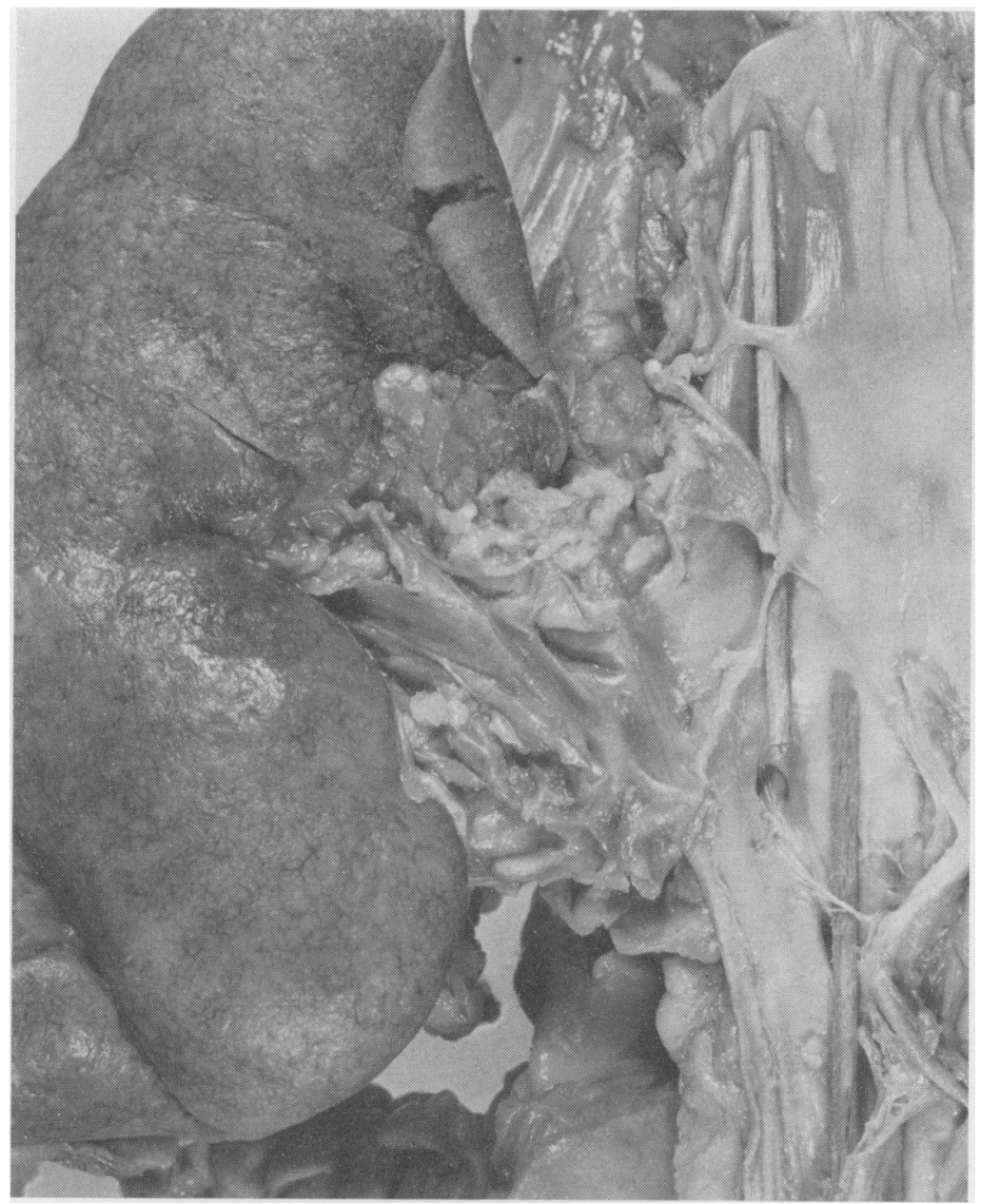

FIG. 5.-Postmortem appearances of kidney and inferior vena cava. Kidney surface scarred and pitted. Venous bands and webs in inferior vena cava and right renal vein.

was thin and corticomedullary demarcation poor (Fig. 4). Though the capsule stripped easily, the renal surface was scarred and pitted (Fig. 5). The inferior vena cava contained no recent antemortem thrombi but numerous venous bands and webs formed by organisation and recanalisation of old thrombi were found from a point just above the renal veins to the lowest point in the femoral veins examined in the thigh (Fig. 5). The number of bands was greater the lower the position of the veins and they were most severe and numerous in the veins of the thigh. Venous bands were also present in the right renal vein but the left renal vein appeared completely clear of organised thrombus. The heart showed fibrinous pericarditis, left ventricular hypertrophy and small friable vegetations, $5 \mathrm{~mm}$. in diameter on the anterior and posterior cusps of the mitral valve. The lungs showed congestion, œdema and early bronchopneumonia. The only other abnormalities were small gastric mucosal hæmor- rhages, cholesterolosis of the gall bladder and hypoplastic adrenal glands.

Histology showed, in the kidneys, patchy thickening of the basement membrane, gross in many of the affected glomeruli. Much periglomerular fibroelastosis was evident in many instances obliterating Bowman's capsule. There was widespread shrinkage, fibrosis and hyalinisation of glomeruli with secondary loss of tubules. Considerable accumulations of lymphocytes and some interstitial fibrosis were present and renal arteries showed medial hypertrophy and intimal fibroelastosis (Fig. 6).

Histology of the venous bands in the inferior vena cava and femoral veins showed them to consist of dense fibroelastic tissue indicating that recanalisation was completed a long time ago.

\section{Discussion}

There seems no doubt that the patient sustained 


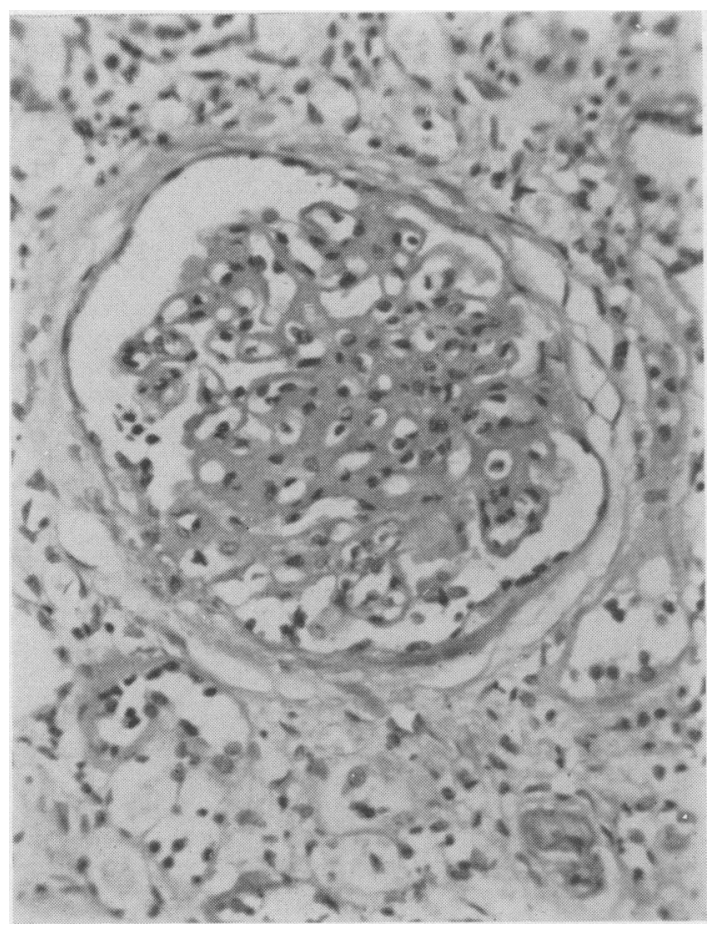

FIG. 6.--Histological appearances of kidney at postmortem.

a traumatic thrombosis of the right femoral vein which spread to involve the inferior vena cava and the renal veins producing a nephrotic syndrome. The histological appearances of the renal biopsy one year after the initial injury showed that gross renal changes had by then developed. The autopsy demonstrated that the inferior vena cava and renal veins had recanalised either naturally or as a result of anticoagulant therapy and the histology of the venous bands suggested that this occurred a long time before death. The clinical course and the postmortem findings indicated that despite this restoration of venous outflow from the kidneys the renal glomerular lesions had progressed and that renal function became further impaired by pyelonephritis and ischæmic changes secondary to hypertension.

The only therapeutic measures which appeared to have any beneficial effect were the high protein feeding which despite heavy proteinuria restored the serum albumin to levels sufficient to prevent hypoproteinæmic œdema, and sulphonamides and antibiotics which controlled secondary pyelonephritis. As in other patients with nephrotic syndrome associated with renal vein thrombosis which we have treated, steroid therapy failed to diminish urinary protein loss. To what extent anticoagulants were responsible for the recanalisation of the inferior vena cava and the renal veins it is impossible to say but they certainly did not halt the inexorable march of renal destruction.

We are greatly indebted to Dr. J. F. Soothill for the immunochemical clearances.

\section{REFERENCES}

Blainey, J. D., BreWer, D. B., HardWicke, J., and SoOTHiLl, J. F. (1960): The Nephrotic Syndrome, Quart. J. Med., 29, 235.

BLAINEY, J. D., HARDWICKe, J., and WhitField, A. G. W. (1954): The Nephrotic Syndrome Associated with Thrombosis of the Renal Veins, Lancet, ii, 1208.

Derow, H. A., Schlesinger, M. J., and Savitz, K. A. (1939): Chronic Progressive Occlusion of the Inferior Vena Cava and the Renal and Portal Veins, Arch. intern. Med., 63, 626.

HarRison, C. V., Milne, M. D., and Steiner, R. E. (1956): Clinical Aspects of Renal Vein Thrombosis, Quart. J. Med., 25, 285.

Hasson, J., Berkman, J. I., Parker, J. G., and RIFKIN, H. (1957): A Clinicopathologic Study of Chronic Renal Vein Thrombosis in Adults, Ann. intern. Med., 47, 493.

Pollak, V. E., Kark, R. M., Pirani, C. L., Shafter, H. A., and MUEHRCKE, R. C. (1956): Renal Vein Thrombosis and the Nephrotic Syndrome, Amer. J. Med., 21, 496.

Rowntree, L. G., Fitz, R., and Gerachty, J. T. (1913): The Effects of Experimental Chronic Passive Congestion on Renal Function, Arch. intern. Med., 11, 121.

ShatTock, S. G. (1913): Occlusion of the Inferior Vena Cava as a Result of Internal Trauma (Dissecting Varix?), Proc. roy. Soc. Med., 6, 126.

\title{
HISTIOCYTOSIS $\mathrm{X}$
}

\author{
W. H. H. Garvie, M.B., F.R.C.S. \\ Late Surgical Registrar \\ Royal Marsden Hospital, London, S.W.3.
}

THE SUGGestion that eosinophilic granuloma, Schüller-Christian's disease and Letterer-Siwe's disease are but various expressions of the same illness was advanced by Farber (1941), Green and Farber (1942) and Jaffe and Lichtenstein (1944). The disease entity was called "Histiocytosis X" by Lichtenstein (1953). This integration of the three diseases has not, however, been accepted by everyone (McGavran and Spady, 1960).
The following case is reported because it gives further evidence in support of this unifying concept. Some additional information about this rare condition is also presented.

\section{Case Report}

T.Y., a female infant aged 15 months, was admitted to a London hospital on December 20,1963. She had been in good health until seven weeks before her 